\title{
Receptor of ghrelin is expressed in cutaneous neurofibromas of individuals with neurofibromatosis 1
}

\author{
Rafaela E. Rozza-de-Menezes 1,2,3, Nicolle C. Gaglionone1, Raquel M. Andrade-Losso 1,2, Orlando H. K. Siqueira", \\ Lilian M. Almeida ${ }^{1,2}$, Kamila da S. Peruzini ${ }^{5}$, Marco A. C. Guimarães-Filho ${ }^{4}$, Carolina I. Brum ${ }^{6}$, Mauro Geller ${ }^{7,8}$ \\ and Karin S. Cunha $a^{1,2,6^{*}}$
}

\begin{abstract}
Background: Multiple cutaneous neurofibromas are a hallmark of neurofibromatosis 1 (NF1). They begin to appear during puberty and increase in number and volume during pregnancy, suggesting a hormonal influence. Ghrelin is a hormone that acts via growth hormone secretagogue receptor (GHS-R), which is overexpressed in many neoplasms and is involved in tumorigenesis. We aimed to investigate GHS-R expression in NF1 cutaneous neurofibromas and its relationship with tumors volume, and patient's age and gender.

Results: Sample comprised 108 cutaneous neurofibromas (55 large and 53 small tumors) from 55 NF1 individuals. GHS-R expression was investigated by immunohistochemistry in tissue micro and macroarrays and quantified using a digital computer-assisted method. All neurofibromas expressed GHS-R, with a percentage of positive cells ranging from $4.9 \%$ to $76.1 \%$. Large neurofibromas expressed more GHS-R than the small ones. The percentage of GHS-Rpositive cells and intensity of GHS-R expression were positively correlated with neurofibromas volume. GHS-R expression was more common in female gender.

Conclusions: GHS-R is expressed in cutaneous neurofibromas. Larger neurofibromas have a higher percentage of positive cells and higher GHS-R intensity. Based on our results we speculate that ghrelin may have an action on the tumorigenesis of cutaneous neurofibromas. Future studies are required to understand the role of ghrelin in the pathogenesis of NF1-associated cutaneous neurofibroma.
\end{abstract}

Keywords: Neurofibromatosis 1, Neurofibroma, Ghrelin, Ghrelin receptor

\section{Background}

Multiple cutaneous neurofibromas (cNfs) are a hallmark of neurofibromatosis 1 (NF1). They begin to appear during puberty and increase in number and volume during pregnancy [1-3], suggesting a hormonal influence. Most neurofibromas express progesterone and androgen receptors $[4,5]$ and in vitro and in vivo studies have shown that neurofibromas grow in the presence of sex hormones [6-8].

\footnotetext{
* Correspondence: karingcunha@gmail.com

${ }^{1}$ Graduate Program in Pathology, School of Medicine, Hospital Universitário Antônio Pedro, Universidade Federal Fluminense, Av. Marquês do Paraná, 303, 40 andar, sala 01 - Centro, Niterói, RJ 24033-900, Brazil

${ }^{2}$ Neurofibromatosis National Center (Centro Nacional de Neurofibromatose), Rio de Janeiro, RJ, Brazil

Full list of author information is available at the end of the article
}

Beyond sex hormones, it is possible that other hormones, such as components of growth hormone (GH) axis, could have a role in the pathogenesis of NF1associated neurofibromas. Most NF1 neurofibromas express $\mathrm{GH}$ receptors, which suggests that $\mathrm{GH}$ exerts a direct effect on these neoplasms [3, 9]. Ghrelin is another component of $\mathrm{GH}$ axis and presents many physiological functions in diverse organs [10]. Ghrelin acts through GH secretagogue receptor (GHS-R) [10]. The classical GHS-R is GHS-R1a, which binds to ghrelin [10]. GHS-R1b is a truncated variant without highaffinity ghrelin binding, with an unclear physiological role. GHS-R1b is expressed in many organs/tissues [1115], and is also overexpressed in many neoplasms and involved in tumorigenesis [16-22]. Ghrelin promotes 
cell proliferation of hepatoma [16], pancreatic [21], breast [17], prostate [22] and colon cancers [19].

We aimed to investigate GHS-R expression in NF1 cNfs and its relationship with tumors volume, and patient's age and gender.

\section{Methods}

Sixty-two individuals with diagnosis of NF1 based on clinical criteria of National Institutes of Health [23] were included in this study. In order to investigate the heterogeneity of GHS-R expression not only in tumors from different individuals but also in tumors from the same individual, each participant had two lesions compatible with cNfs surgically removed: one of the smallest (with at least $4 \mathrm{~mm}$ of diameter) and one of his/her largest tumors. Clinically, CNfs were classified as cutaneous if they were limited to the skin and, when moved, the skin over it moves together with the tumor [24]. The neurofibromas volume (expressed in $\mathrm{mm}^{3}$ ) was achieved using ellipsoid volume calculation method $(1 / 2 \mathrm{x}$ Length $\mathrm{x}$ Weight x Height) [25].

Samples were handled and processed according to routine histological procedures and a 5- $\mu \mathrm{m}$ haematoxylin/eosin section was used for diagnosis confirmation. We included only non-encapsulated neurofibromas, which represent cNfs $[24,26]$, and those with immunohistochemical heterogeneous S100 expression (1:100; M7240; Dako Corporation, CA/USA). Subcutaneous neurofibromas, which are confined in an intact perineurium/epineurium (localized intraneural neurofibroma) [26, 27], were excluded since they are different from cNfs not only in their clinical and histopathological aspects but also in terms of prognosis [28, 29].

Tissue microarray (TMA) blocks containing samples from large neurofibromas were constructed as previously described [30], using 1.1 diameter cores from three to five representative regions of each tumor. For small neurofibromas, whole specimens were evaluated after inclusion in tissue macroarrays (TMaAs), using a technique developed by Prof. Dias from UFF (data not published). Briefly, after acquisition of each sample and fixation, histological processing was initiated, stopped after paraffin impregnation, and the specimen was kept in properly identified histological cassette until preparation of the TMaA block. After the collection of all the samples to be included in the TMaA, a thin liquid paraffin layer was placed on a metallic mold and the specimens were attached in an orderly fashion according to a location map. Liquid paraffin was then inserted to construct the paraffin block.

GHS-R was demonstrated immunohistochemically. Negative and positive controls were performed by primary antibody omission and use of normal stomach tissue, respectively. Aperio Digital Pathology System (Leica Biosystems, Richmond, IL/USA) was used for automatic immunoquantification. Detailed information about immunohistochemistry and immunoquantification procedures is shown in Additional file 1.

Table 1 Summary GHS-R expression data and statistical findings

\begin{tabular}{|c|c|c|c|}
\hline & \multicolumn{2}{|l|}{ Cutaneous Neurofibromas } & \multirow{3}{*}{ P-value } \\
\hline & Large & Small & \\
\hline & Mean ( \pm standard deviation) & Mean ( \pm standard deviation) & \\
\hline Volume $\left(\mathrm{mm}^{3}\right)$ & $1923( \pm 2349)$ & $63.9( \pm 62.1)$ & $<0.0001^{a}$ \\
\hline Total number of nuclei per neurofibroma & $25,878( \pm 10,979)$ & $5,2016( \pm 27,953)$ & - \\
\hline Number of positive nuclei per neurofibroma & $14,025( \pm 6310)$ & $21,912( \pm 14,146)$ & - \\
\hline Percent of positive nuclei per neurofibroma/n* & $53.6 \%( \pm 9.2) / 48$ & $41.1 \%( \pm 13.1) / 48$ & $<0.0001^{b}$ \\
\hline $\begin{array}{l}\text { Percent of positive nuclei (considering the tumors of the same } \\
\text { individuals with volume difference } \geq 1000 \mathrm{~mm}^{3} \text { )/ } \mathrm{n}^{*}\end{array}$ & $52.9 \%( \pm 8.6) / 24$ & $44.2 \%( \pm 14.4) / 24$ & $0.01^{b}$ \\
\hline $\begin{array}{l}\text { Percent of positive nuclei (considering the tumors of the same } \\
\left.\text { individuals with volume difference of } \geq 3000 \mathrm{~mm}^{3}\right) / \mathrm{n}^{*}\end{array}$ & $53.6 \%( \pm 8.0) / 9$ & $35.4 \%( \pm 16.1) / 9$ & $0.015^{a}$ \\
\hline $\begin{array}{l}\text { Percent of cells with strong staining / Number of tumors with } \\
\text { predominance of cells with strong staining }\end{array}$ & $24.1 \%^{d}( \pm 7.1) / 42^{d}$ & $13.5 \%( \pm 9) / 20$ & $<0.0001^{\mathrm{c}}$ \\
\hline $\begin{array}{l}\text { Percent of cells with moderate staining / Number of tumors } \\
\text { with predominance of cells with moderate staining }\end{array}$ & $17.9 \%^{d}( \pm 4.6) / 13^{d}$ & $13.5 \%( \pm 4.3) / 8$ & \\
\hline $\begin{array}{l}\text { Percent of cells with weak staining / Number of tumors with } \\
\text { predominance of cells with weak staining }\end{array}$ & $11.4 \%$ ( \pm 2.7$) / 0$ (none) & $14.1 \%( \pm 4.2) / 25$ & \\
\hline Area of analysis $\left(\mathrm{mm}^{2}\right)$ & $4.2( \pm 1.7)$ & $10.2( \pm 6.3)$ & - \\
\hline
\end{tabular}

${ }^{*} n$, number of tumors

${ }^{a}$ Wilcoxon rank-sum test

${ }^{\mathrm{b}}$ Paired $t$-test

${ }^{c}$ ANOVA one-way (with Bonferroni correction)

${ }^{d}$ values with statistical difference after Bonferroni correction 
Statistical analyses were performed with SPSS v.20 $\left(\mathrm{IBM}^{\circ}\right)$. Normality was evaluated with Shapiro-Wilk test. ANOVA one-way (with Bonferroni correction), Student's $t$-test, paired $t$-test and Pearson's correlation coefficient were used for variables with normal distribution, and Wilcoxon rank-sum test and Spearman's correlation coefficient for non-normal distribution variables. Simple linear regression was used to summarize the relationship between the percentage of GHS-R positive cells and volume of tumors. $P$-values $\leq 0.05$ were considered significant.

\section{Results}

Table 1 shows a summary of GHS-R expression data and statistical findings. Additional file 2 (Table S1) and Additional file 3 (Table S2) show clinical data and detailed GHS-R expression data, respectively. After excluding cases without microscopic confirmation of cNf $(n=4)$ and losses during immunohistochemistry $(n=12)$, the sample comprised 55 large and 53 small neurofibromas from 55 participants. All neurofibromas expressed S100. For paired tests, large $(n=48)$ and small tumors $(n=48)$ from the same individuals were considered. Paired values of volume of large versus small neurofibromas were different ( $p<0.0001$, Wilcoxon rank-sum test).

All neurofibromas expressed GHS-R, which was investigated with an antibody against both GHS-R isoforms. In the tumor area, positivity was seen in fusiform cells (although not all were positive), mast cells, which were identified by their morphology, and endothelial cells of blood vessels (Fig. 1a-e). In the area surrounding the neurofibromas, dermis was negative, but epidermis, skin annexes, nerves, and endothelial cells of blood vessels were positive to GHS-R (Fig. 1f-h).

In the neurofibroma area, the percentage of positive cells to GHS-R varied from 4.9 to $76.1 \%$ (mean $=47.5 \%$; \pm 12.8 ). Large neurofibromas had a higher percentage of GHS-R-positive cells than small ones $(p<0.0001$, paired $t$-test). Considering the small and large neurofibromas from the same individuals with volume difference $\geq$ $1000 \mathrm{~mm}^{3}$, the largest had a higher percentage of positive cells $(p=0.01$, paired $t$-test). Significant statistical differences were also observed when considering neurofibromas with volume difference $\geq 3000 \mathrm{~mm}^{3}$ ( $p=0.015$, respectively, Wilcoxon rank-sum test). Considering all tumors, the percentage of GHS-R-positive cells was positively correlated with neurofibromas volume ( $p<$ 0.0001, Spearman's correlation coefficient). Linear regression revealed positive correlation between percentage of GHS-R-positive cells and tumors volume ( $p=$ $0.01)$. The percentage of positive cells was not related with patient's age $(p=0.62$, Pearson's correlation coefficient), but was positively associated with female gender ( $p=0.0005$, Student's t-test).

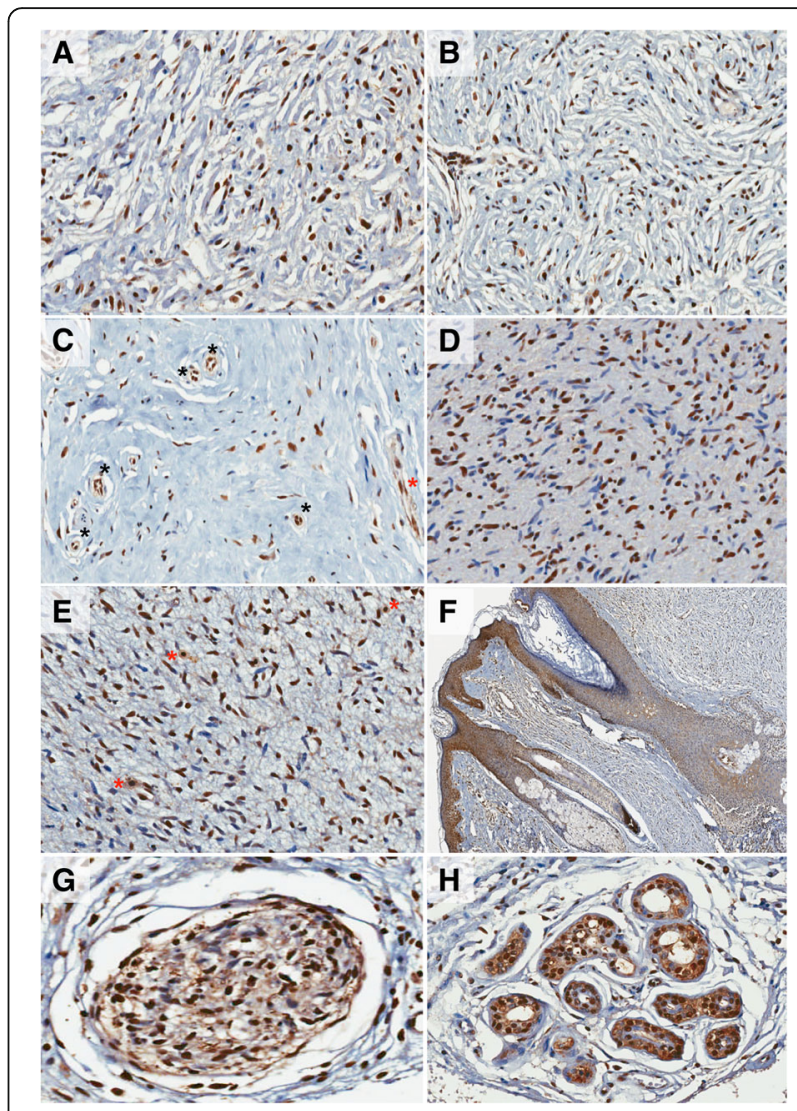

Fig. 1 Expression of GHS-R in neurofibromas and other structures. Legend: (a - e) Neurofibromas expressing GHS-R. Most spindle cells showed nuclear expression, but some also presented cytoplasmic GHS-R expression. (200x); (c) Asterisks show GHS-R expression in tumor endothelial cells (nucleus and cytoplasm). Black asterisks: transversal cut of blood vessels. Blue asterisk: longitudinal cut of a blood vessel; (e) Asterisks show expression of GHS-R in mast cells. f GHS-R expression in epidermis, hair follicles, and sebaceous glands (100x). g GHS-R expression in nerve fascicle (400x); (h) GHS-R expression in sweat glands (200x)

The percentage of cells with weak, moderate and strong GHS-R staining in large and small neurofibromas was significant different $(p<0.0001$, ANOVA one-way with Bonferroni correction, Fig. 2). Large neurofibromas had a higher percentage of cells with moderate/strong staining than small neurofibromas $(p<0.0001$, ANOVA one-way with Bonferroni correction, Fig. 2).

\section{Discussion}

We show for the first time that $\mathrm{cNfs}$ express GHS-R. Expression of GHS-R was seen in fusiform cells of the tumors. Neurofibromas are composed of Schwann cells [31], as well as perineurial-like cells, fibroblasts, mast cells, and axons [26]. Under optical microscopy, based on their morphology, Schwann cells, perineural-like cells and fibroblasts cannot be distinguished, since all present a fusiform aspect. One limitation of this study was the 


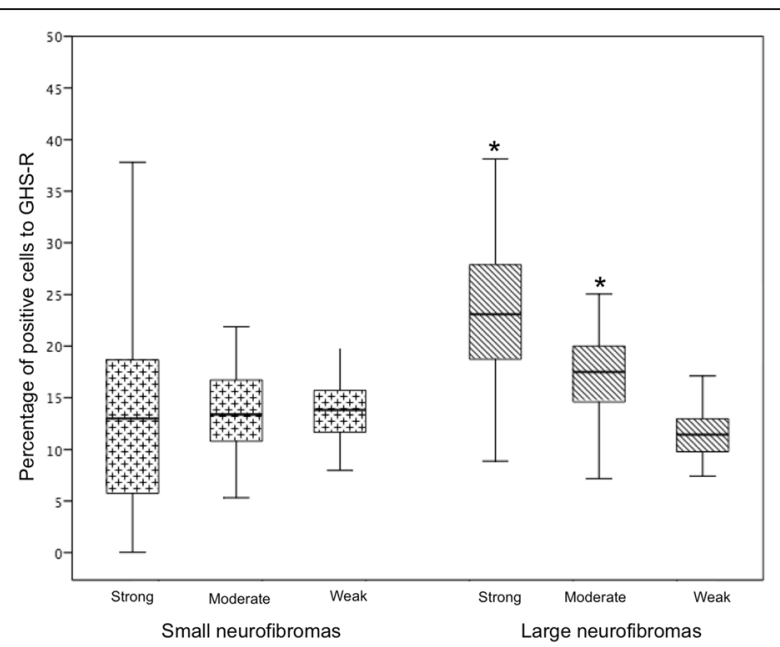

Fig. 2 Percentage of GHS-R positive cells according to the staining intensity in small and large neurofibromas of individuals with neurofibromatosis 1. Legend: Large neurofibromas had a higher percentage of moderate/strong staining cells than small neurofibromas (* indicates $p<0.0001$, ANOVA one-way with Bonferroni correction)

use of a one staining immunohistochemistry. Other studies are necessary to know which fusiform cells in cutaneous neurofibromas express GHS-R. Mast cells in cNfs also expressed GHS-R and it is known that mast cells are important to neurofibroma tumorigenesis [32]. Future studies are necessary to determine the action of ghrelin on different cells of neurofibromas.

Ghrelin is proangiogenic and normal human endothelial cells express GHS-R [33]. Endothelial cells of blood vessels in the $\mathrm{cNfs}$ and also in the surrounding normal dermis were positive to GHS-R. Neurofibromas are highly vascularized and the ghrelin action in promoting their growth by enhancing angiogenesis should be further investigated.

In conclusion, we show that GHS-R is expressed in cNfs. Larger neurofibromas have a higher percentage of positive cells and higher GHS-R intensity. Moreover, GHS-R expression was more common in female gender. Based on our results we speculate that ghrelin may have an action on the tumorigenesis of cNfs. Future studies are required to understand the role of ghrelin in the pathogenesis of NF1-associated cutaneous neurofibroma.

\section{Additional files}

Additional file 1: Supplementary information - Methods. Detailed information about immunohistochemistry and immunoquantification. (PDF $40 \mathrm{~kb}$ )

Additional file 2: Table S1. Clinical data of the individuals with neurofibromatosis 1 and neurofibromas included in the study. (PDF 59 kb)

Additional file 3: Table S2. Results of GHS-R expression in neurofibromas. (PDF 79 kb)

\section{Abbreviations}

cNf: Cutaneous neurofibroma; GH: Growth hormone; GHS-R: GH secretagogue receptor; GHS-R1a: GHS-R type 1a; GHS-R1b: GHS-R type 1b; NF1: Neurofibromatosis 1; TMA: Tissue microarray; TMaA: Tissue macroarray

\section{Acknowledgements}

We thank Prof. Eliane Pedra Dias, from the Department of Pathology of the School of Medicine of Universidade Federal Fluminense, for assistance with the construction of tissue macroarray paraffin blocks.

\section{Funding}

Supported by FAPERJ (Fundação de Amparo à Pesquisa do Estado do Rio de Janeiro), Brazil, under number E-26/110/409/2011 (to K.S.C.).

\section{Availability of data and materials}

The datasets supporting the results of this article are included within the article and in Additional files.

\section{Authors' contributions}

KSC conceptualized, designed, acquired financial support, participated in and coordinated the study, as well wrote the manuscript. KSC, RERM, NCG, RMAL, LMSA, and KSP attended the participants. OHKO and MACGF performed the surgeries. KSC, CAIB and NGC were involved in the histopathological diagnosis of neurofibromas. RERM, NGC, RMAL and LMSA constructed the TMA and TMaA paraffin blocks and performed the immunohistochemistry technique. KSC, RERM, NCG, and RMAL analyzed the immunohistochemical results. KSC and RERM performed the digital computer analysis of the immunohistochemical results. RERM was involved in statistical analysis and participated in writing the manuscript. MG contributed to the project design and critically reviewed the manuscript. All authors had given the final approval of the version to be published.

\section{Ethics approval and consent to participate}

The ethics committee of the Universidade Federal Fluminense, Niterói, RJ, Brazil (\#126/11) approved this study. All patients provided informed consent.

\section{Competing interests}

The authors declare that they have no competing interests.

\section{Publisher's Note}

Springer Nature remains neutral with regard to jurisdictional claims in published maps and institutional affiliations.

\section{Author details}

${ }^{1}$ Graduate Program in Pathology, School of Medicine, Hospital Universitário Antônio Pedro, Universidade Federal Fluminense, Av. Marquês do Paraná, 303, 40 andar, sala 01 - Centro, Niterói, RJ 24033-900, Brazil.

${ }^{2}$ Neurofibromatosis National Center (Centro Nacional de Neurofibromatose), Rio de Janeiro, RJ, Brazil. ${ }^{3}$ School of Dentistry, Health Institute of Nova Friburgo, Universidade Federal Fluminense, Nova Friburgo, RJ, Brazil. ${ }^{4}$ Department of General and Specialized Surgery, School of Medicine, Universidade Federal Fluminense, Niterói, RJ, Brazil. ${ }^{5}$ School of Medicine, Universidade Federal Fluminense, Niterói, RJ, Brazil. ${ }^{6}$ Department of Pathology, School of Medicine, Universidade Federal Fluminense, Niterói, RJ, Brazil. ${ }^{7}$ Department of Immunology and Microbiology, School of Medicine, Centro Universitário Serra dos Órgãos (UNIFESO), Teresópolis, RJ, Brazil.

${ }^{8}$ Instituto de Puericultura e Pediatria Martagão Gesteira, School of Medicine, Universidade Federal do Rio de Janeiro, Rio de Janeiro, RJ, Brazil.

Received: 8 September 2017 Accepted: 5 December 2017 Published online: 20 December 2017

References

1. Ansari A, Nagamani M. Pregnancy and neurofibromatosis (von Recklinghausen's disease). Obstet Gynecol. 1976;47:30s.

2. Dugoff L, Sujansky E. Neurofibromatosis type 1 and pregnancy. Am J Med Genet. 1996;66:7-10.

3. Cunha KSG, Barboza EP, Fonseca ECD. Identification of growth hormone receptor in localised neurofibromas of patients with neurofibromatosis type 1. J Clin Pathol. 2003;56:758-63. 
4. Geller M, Mezitis SGE, Nunes FP, Ribeiro MG, de QC AAP, Bronstein MD, et al. Progesterone and Estrogen receptors in Neurofibromas of patients with NF1. Clin Med Pathol. 2008;1:93-7.

5. McLaughlin ME, Jacks T. Progesterone receptor expression in neurofibromas. Cancer Res. 2003;63:752-5.

6. Overdiek A, Winner U, Mayatepek E, Rosenbaum T. Schwann cells from human neurofibromas show increased proliferation rates under the influence of progesterone. Pediatr Res. 2008;64:40-3.

7. Roth TM, Ramamurthy P, Muir D, Wallace MR, Zhu Y, Chang L, et al. Influence of hormones and hormone metabolites on the growth of Schwann cells derived from embryonic stem cells and on tumor cell lines expressing variable levels of neurofibromin. Dev Dyn. 2008;237: 513-24.

8. Li H, Zhang X, Fishbein L, Kweh F, Campbell-Thompson M, Perrin GQ, et al. Analysis of steroid hormone effects on xenografted human NF1 tumor schwann cells. Cancer Biol Ther. 2010;10:758-64.

9. Cunha K, Barboza E, Fonseca ECD. Identification of growth hormone receptor in plexiform neurofibromas of patients with neurofibromatosis type 1. Clin Sao Paulo. 2008;63:39-42.

10. Nikolopoulos D, Theocharis S, Kouraklis G. Ghrelin: a potential therapeutic target for cancer. Regul Pept. 2010;163:7-17.

11. Majchrzak K, Szyszko K, Pawłowski KM, Motyl T, Król M. A role of ghrelin in cancerogenesis. Pol J Vet Sci. 2012;15:189-97.

12. Tena-Sempere M. Ghrelin, the gonadal axis and the onset of puberty. Endocr Dev. 2013:25:69-82.

13. Jeffery PL, Herington AC, Chopin LK. The potential autocrine/paracrine roles of ghrelin and its receptor in hormone-dependent cancer. Cytokine Growth Factor Rev. 2003;14:113-22.

14. Tena-Sempere M. Exploring the role of ghrelin as novel regulator of gonadal function. Growth Horm IGF Res Off J Growth Horm Res Soc Int IGF Res Soc. 2005;15:83-8.

15. Camiña JP, Carreira MC, Micic D, Pombo M, Kelestimur F, Dieguez C, et al. Regulation of ghrelin secretion and action. Endocrine. 2003;22:5-12.

16. Murata M, Okimura Y, lida K, Matsumoto M, Sowa H, Kaji H, et al. Ghrelin modulates the downstream molecules of insulin signaling in hepatoma cells. J Biol Chem. 2002;277:5667-74.

17. Jeffery PL, Murray RE, Yeh AH, McNamara JF, Duncan RP, Francis GD, et al. Expression and function of the ghrelin axis, including a novel preproghrelin isoform, in human breast cancer tissues and cell lines. Endocr Relat Cancer. 2005;12:839-50.

18. Cassoni P, Allia E, Marrocco T, Ghè C, Ghigo E, Muccioli G, et al. Ghrelin and cortistatin in lung cancer: expression of peptides and related receptors in human primary tumors and in vitro effect on the $\mathrm{H} 345$ small cell carcinoma cell line. J Endocrinol Investig. 2006;29:781-90.

19. Lien G-S, Lin C-H, Yang Y-L, Wu M-S, Chen B-C. Ghrelin induces colon cancer cell proliferation through the GHS-R, Ras, PI3K, Akt, and mTOR signaling pathways. Eur J Pharmacol. 2016;776:124-31.

20. Cassoni P, Ghé C, Marrocco T, Tarabra E, Allia E, Catapano F, et al. Expression of ghrelin and biological activity of specific receptors for ghrelin and desacyl ghrelin in human prostate neoplasms and related cell lines. Eur J Endocrinol Eur Fed Endocr Soc. 2004:150:173-84.

21. Duxbury MS, Waseem T, Ito H, Robinson MK, Zinner MJ, Ashley SW, et al. Ghrelin promotes pancreatic adenocarcinoma cellular proliferation and invasiveness. Biochem Biophys Res Commun. 2003;309:464-8.

22. Yeh AH, Jeffery PL, Duncan RP, Herington AC, Chopin LK. Ghrelin and a novel preproghrelin isoform are highly expressed in prostate cancer and ghrelin activates mitogen-activated protein kinase in prostate cancer. Clin Cancer Res Off J Am Assoc Cancer Res. 2005;11:8295-303.

23. Stumpf DA, Alksne JF, Annegers JF, Brown SS, Conneally PM, Housman D, et al. Neurofibromatosis. Conference statement. National Institutes of Health consensus development conference. Arch Neurol. 1988;45:575.

24. Riccardi VM. The genetic predisposition to and histogenesis of neurofibromas and neurofibrosarcoma in neurofibromatosis type 1. Neurosurg Focus. 2007;22:E3.

25. Tomayko MM, Reynolds CP. Determination of subcutaneous tumor size in athymic (nude) mice. Cancer Chemother Pharmacol. 1989;24:148-54.

26. Antonescu CR, Scheithauer BW. Tumors of the Peripheral Nervous System. Rockville: American Registry of Pathology; 2013.

27. Gupta G, Maniker A. Malignant peripheral nerve sheath tumors. Neurosurg Focus. 2007;22:E12.
28. Ferner RE. Neurofibromatosis 1 and neurofibromatosis 2: a twenty first century perspective. Lancet Neurol. 2007:6:340-51.

29. Khosrotehrani K, Bastuji-Garin S, Riccardi VM, Birch P, Friedman JM, Wolkenstein P. Subcutaneous neurofibromas are associated with mortality in neurofibromatosis 1: a cohort study of 703 patients. Am J Med Genet A. 2005;132A:49-53.

30. Cunha KSG, Caruso AC, Gonçalves AS, Bernardo VG, Pires ARC, da Fonseca EC, et al. Validation of tissue microarray technology in malignant peripheral nerve sheath tumours. J Clin Pathol. 2009;62:629-33.

31. Peltonen J, Jaakkola S, Lebwohl M, Renvall S, Risteli L, Virtanen I, et al. Cellular differentiation and expression of matrix genes in type 1 neurofibromatosis. Lab Investig J Tech Methods Pathol. 1988;59:760-71.

32. Staser K, Yang F-C, Clapp DW. Pathogenesis of plexiform neurofibroma: tumor-stromal/hematopoietic interactions in tumor progression. Annu Rev Pathol. 2012:7:469-95.

33. Li A, Cheng G, Zhu GH, Tarnawski AS. Ghrelin stimulates angiogenesis in human microvascular endothelial cells: implications beyond GH release. Biochem Biophys Res Commun. 2007;353:238-43.

\section{Submit your next manuscript to BioMed Central and we will help you at every step:}

- We accept pre-submission inquiries

- Our selector tool helps you to find the most relevant journal

- We provide round the clock customer support

- Convenient online submission

- Thorough peer review

- Inclusion in PubMed and all major indexing services

- Maximum visibility for your research

Submit your manuscript at www.biomedcentral.com/submit
) Biomed Central 